\title{
Contribution of nitrogen from sugarcane harvest residues and urea for crop nutrition
}

\author{
Caio Fortes ${ }^{1 *}$, André Cesar Vitti ${ }^{2}$, Rafael Otto ${ }^{3}$, Danilo Alves Ferreira ${ }^{3}$, Henrique Coutinho Junqueira Franco ${ }^{4}$, Paulo Cesar \\ Ocheuze Trivelin ${ }^{5}$
}

\author{
${ }^{1}$ BP Biocombustíveis S/A, Av. das Nações Unidas, 12.399 - \\ 04578-000 - São Paulo, SP - Brasil. \\ ${ }^{2}$ Agencia Paulista de Tecnologia dos Agronegócios, Rod. SP \\ 127, km 69 - 13400-970 - Piracicaba, SP - Brasil. \\ 3USP/ESALQ, Av. Pádua Dias, 11 - 13418-900 - Piracicaba, \\ $\mathrm{SP}$ - Brasil. \\ ${ }^{4}$ CNPEM/CTBE - Laboratório Nacional de Ciência e \\ Tecnologia do Bioetanol, Polo II de Alta Tecnologia, R. \\ Giuseppe Máximo Scolfaro, 10.000 - 13083-970 - \\ Campinas, SP - Brasil. \\ 5USP/CENA, Av. Centenário, 303 - 13400-970 - Piracicaba, \\ $\mathrm{SP}$ - Brasil. \\ *Corresponding author <caio.fortes@bp.com>
}

Edited by: José Miguel Reichert

Received July 30, 2012

Accepted February 8, 2013
ABSTRACT: Sugarcane (Saccharum spp.) harvested without burning provides a substantial amount of remains (trash) on soil profiles which can be decomposed and release nutrients contributing to reduce fertilizer needs. The contribution of nitrogen $(\mathrm{N})$ from sugarcane plant residues and fertilizer in sugarcane nutrition was assessed. Plant cane treatments were micro plots of ${ }^{15} \mathrm{~N}$ labeled urea, sugarcane trash and root system; the last two to simulate the previous crop residues incorporated into the soil after crop renewal. For ratoons, $\mathrm{N}$-ammonium nitrate (N-AN) micro plots, $150 \mathrm{~kg} \mathrm{ha}^{-1}$ of N-AN and control $\left(0 \mathrm{~kg} \mathrm{ha}^{-1}\right)$ were set up to evaluate the contribution of trash in $\mathrm{N}$ supply and quantify the effects of $\mathrm{N}$-fertilizer on $\mathrm{N}$-trash mineralization. The $\mathrm{N}$ balances derived from each ${ }^{15} \mathrm{~N}$ source were calculated after four crops and resulted in: ${ }^{15} \mathrm{~N}$-urea applied at planting, $31 \%$ was recovered by plant cane, $12 \%$ by the following ratoons, $20 \%$ remained in the soil and $37 \%$ was not found in the soil-system (NOC). For crop residues ${ }^{15} \mathrm{~N}$-trash + roots 26 $\%$ was recovered by sugarcane, $51 \%$ remained in soil, and $23 \%$ was NOC. N-fertilizer applied to ratoons nearly doubled the amount of $\mathrm{N}$ from green harvest residues recovered by sugarcane; 17 vs. $31 \%$. Water balances and crop evapotranspiration were correlated with ${ }^{15} \mathrm{~N}$-sources recoveries and cumulative $\mathrm{N}$ recovery presented a positive correlation with evapotranspiration (2005 to 2009). The ${ }^{15} \mathrm{~N}$ balances indicated that crop residues are supplementary sources of $\mathrm{N}$ for sugarcane and may contribute to reduce $\mathrm{N}$ fertilizer needs since trash is annually added to the soil. Keywords: Saccharum spp., ${ }^{15} \mathrm{~N}$ isotope, $\mathrm{N}$ balance, urea, straw, roots and rhizomes

\section{Introduction}

Sugarcane (Saccharum spp.) is a widely known bioenergy crop due to its large biomass production which liaise for global greenhouse gases (GHG) emission targets and benefits preservation of soil and water resources (Macedo et al., 2008).

São Paulo State is the largest producer in Brazil, where more than $70 \%$ of the overall sugarcane production is managed as green cane under trash blanket (GCTB) or without trash (or straw) burning prior to harvest (Lucon and Goldemberg, 2010). The GCTB provides annually 5 to $20 \mathrm{Mg} \mathrm{ha}^{-1}$ of remains which contribute to increase soil carbon $(\mathrm{C})$, organic matter (Dourado Neto et al., 2010) and to enhance soil physico-chemical and biological properties (Spain and Hodgen, 1994). Further, in field renewal areas, the shoots and roots from the previous crop are also part of the trash and conserve nutrients in the soil-plant system (Franco et al., 2011; Fortes et al., 2012; Hemwong et al., 2009).

The dynamics of decomposition and nutrient release from plant residues depends on environmental factors such as evapotranspiration, soil moisture and aeration (Robertson and Thorburn, 2007a) and the biochemical composition of residues or C:N ratio, nutrients, lignin, cellulose, hemicellulose and polyphenols content (Abiven et al., 2005; Zhang et al., 2008).

Sugarcane trash can provide 40 to $120 \mathrm{~kg} \mathrm{ha}^{-1}$ of $\mathrm{N}$ year $^{-1}$ (Franco et al., 2010; Oliveira et al., 2002; Robertson and Thorburn, 2007b) and, on average, sugarcane trash contains 450 and $4.5 \mathrm{~g} \mathrm{~kg}^{-1}$ of $\mathrm{C}$ and $\mathrm{N}$, respectively, thus a C:N ratio about 100:1. This composition affords intense
$\mathrm{N}$ immobilization by the soil microbial biomass and a slow net mineralization of $\mathrm{C}$ and $\mathrm{N}$. Likewise, the recovery rates of $\mathrm{N}$ from crop residues incorporated into the soil varied from $2 \%$ to $15 \%$ of the total $\mathrm{N}$ contained in such residues (Ambrosano et al., 2005; Basanta et al., 2003; Chapman et al., 1992; Gava et al., 2005; Meier et al., 2006; Ng Kee Kwong et al., 1987; Trivelin et al., 2002; Vitti et al., 2010).

Remarkably, most of these citations considered one or two cropping cycles and multitemporal results such as that published by Dourado Neto et al. (2010) are uncommon. Those authors studied the recovery of $\mathrm{N}$ from fertilizers and residues by tropical crops during three to six consecutive cycles in various locations and concluded that crop residues are vital for yield maintenance on those highly weathered environments. Therefore, a better understanding on crop residue decomposition dynamics, nutrient availability and release rates to plants can improve the $\mathrm{N}$ fertilization management for high yielding sugarcane fields, especially when considering long-term crop replacement. The objective of this study was to assess the contribution of $\mathrm{N}$ from urea, trash and root system from the last ratoon and trash from the plant cane harvested without burning to sugarcane nutrition throughout four successive crops.

\section{Materials and Methods}

Experimental site and climatic data of the evaluated cropping cycles (2005 to 2009)

The sugarcane was planted on Mar. $2^{\text {nd }}, 2005$ in Jaboticabal, state of São Paulo, Brazil $\left(21^{\circ} 17^{\prime} 20^{\prime \prime} \mathrm{S}\right.$ $48^{\circ} 12^{\prime} 30^{\prime \prime} \mathrm{W}$ ) on a clayey (628 $\mathrm{g} \mathrm{kg}^{-1}$ of clay) Rhodic Eu- 
trudox (USDA, 2006) formerly cropped with the sugarcane variety RB855536 during seven cycles under GCTB. The reduced tillage was adopted as the soil preparation method; the previous ratoon was eradicated with glyphosate and followed by a single subsoiling operation (0.45 $\mathrm{m}$ depth) in order to preserve part of the plant residues on soil surface. The topsoil 0-0.25 m layer was sampled and analyzed according to van Raij et al. (2001) immediately before seed bed preparation for the plant cane, and indicated: $\mathrm{pH}\left(0.01 \mathrm{M} \mathrm{CaCl}_{2}\right) 5.2$; soil organic matter (SOM) $31 \mathrm{~g} \mathrm{dm}^{-3}$; P $42 \mathrm{mg} \mathrm{dm}^{-3} ; \mathrm{K} \mathrm{3.1,} \mathrm{Ca} \mathrm{31,} \mathrm{Mg}$ 9 and cationic exchange capacity (CEC) $77.4 \mathrm{mmol}_{\mathrm{c}} \mathrm{dm}^{-3}$. Plant cane fertilization was 80,120 and $120 \mathrm{~kg} \mathrm{ha}^{-1}$ of $\mathrm{N}, \mathrm{P}_{2} \mathrm{O}_{5}$ and $\mathrm{K}_{2} \mathrm{O}$, respectively, incorporated in furrows spaced $1.5 \mathrm{~m}$ apart and a planting density of 15 to 20 viable buds $\mathrm{m}^{-1}$ of the SP81-3250 sugarcane variety.

Climatic data of the evaluated cropping cycles (2005 to 2009) were collected using an automated weather station. The weather data were used to calculate the crop water balances according to Allen et al. (1998).

\section{${ }^{15} \mathrm{~N}$ micro plots urea and crop residues installation}

Labeled ${ }^{15} \mathrm{~N}$-urea micro plots were set up on a single row segment of $2.0 \mathrm{~m}$ length where the labeled fertilizer was buried into the furrow just before seed (cane stalks) was distributed (Figure 1). In parallel, ${ }^{15} \mathrm{~N}$ labeled sugarcane residues of trash and root system (plus rhizome) were obtained from another field of the same variety, which were previously cropped (RB85-5536). The sugarcane was enriched with ${ }^{15} \mathrm{~N}$ according to Faroni et al. (2008) using a methodology validated by Yasmin et al. (2006), by foliar sprayings with a concentrated ${ }^{15} \mathrm{~N}$ urea solution (atoms \% excess $=28 \%$ ). Afterwards, the cane tops, dry leaves and root system were harvested sepa- rately and chopped in 50-100 mm pieces with a machete in order to simulate the mechanical harvesting and the reduced tillage performed in crop renewal. Then, samples from each part of plant were dried into an oven during $72 \mathrm{~h}$ at $65^{\circ} \mathrm{C}$, homogenized and subsampled for chemical analysis. Subsamples were finely ground 10.25 $\mathrm{mm}$ ) in a Willey mill and the total $\mathrm{C}$ and $\mathrm{N}$ contents (g $\mathrm{kg}^{-1}$ ) and ${ }^{15} \mathrm{~N}$ abundance (Atoms \% excess) were determined in a Hydra 20-20 mass spectrometer (Sercon Co., UK) coupled to an automated $\mathrm{N}$ analyzer ANCA-SGL (Barrie and Prosser, 1996).

The microplots with residues from last harvest (tops and dry leaves) and root system were established applying residues immediately after the inter-row leveling operation (Jun. 2005), in four replicates. The $\mathrm{C}$ and $\mathrm{N}$ concentration $\left(\mathrm{g} \mathrm{kg}^{-1}\right),{ }^{15} \mathrm{~N}$ abundance (atoms \% excess), $\mathrm{C}: \mathrm{N}$ ratio and the total amount of $\mathrm{N}$ applied in the micro plots through the ${ }^{15} \mathrm{~N}$ sources are described in Table 1.

Both residues were applied in $2.0 \times 1.5 \mathrm{~m} \mathrm{mi-}$ croplots perpendicularly to the cane rows; hence using two half inter-rows as described in Figure 1. The above ground plant material from the last harvest was slightly incorporated into the soil (approximately $0.05 \mathrm{~m}$ ), covered with a nylon screen (0.03 m mesh) and fixed on soil surface with staples. This was performed to prevent the entrance of outer trash from natural leaf senescence or from the mechanical harvesting operation while it allowed the natural decomposition of these residues, as emphasized by Robertson and Thorburn (2007b). For root system residues, they were also incorporated into the soil ( 0.10 to $0.20 \mathrm{~m}$ depth) to simulate the sugarcane rhizomes and roots which remained in the soil after crop renewal (Figure 2).

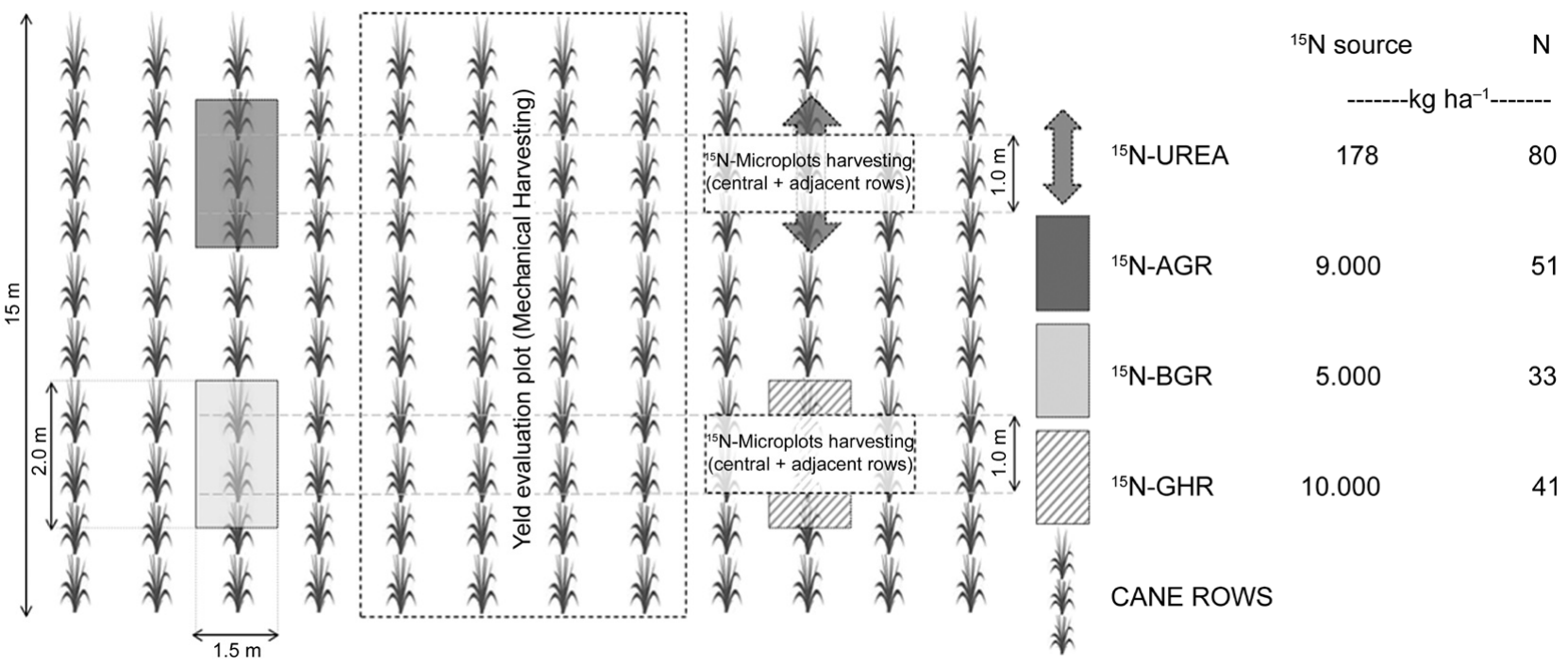

Figure $1-{ }^{15} \mathrm{~N}$-microplot design and amount of ${ }^{15} \mathrm{~N}$ sources employed in field trials.

${ }^{15} \mathrm{~N}-$-UREA = nitrogen fertilizer used at planting $\left({ }^{15} \mathrm{~N}\right.$ labeled urea); ${ }^{15} \mathrm{~N}-\mathrm{AGR}$ and ${ }^{15} \mathrm{~N}-\mathrm{BGR}=$ above ground and below ground residues (dry leaves and rhizomes, variety RB855536, respectively) labeled with ${ }^{15} \mathrm{~N} ;{ }^{15} \mathrm{~N}-\mathrm{GHR}=$ labeled green harvest residues (dry leaves, variety SP81-3250). 
Table 1 - General information of ${ }^{15} \mathrm{~N}$ sources and micro plot installation.

\begin{tabular}{|c|c|c|c|c|c|c|c|c|}
\hline${ }^{15} \mathrm{~N} \mathrm{Source}^{\dagger}$ & Amount & $\begin{array}{l}\text { Installation } \\
\text { date }\end{array}$ & $\mathrm{N}$ & ${ }^{15} \mathrm{~N}$ & C & $\mathrm{C}: \mathrm{N}$ & $\mathrm{N}$ & C \\
\hline & $\mathrm{kg} \mathrm{ha}^{-1}$ & \multicolumn{5}{|c|}{ - $\%$} & \multicolumn{2}{|c|}{ — $\mathrm{kg} \mathrm{ha}^{-1}$} \\
\hline Urea & 178 & 05/03/05 & 45 & 5.17 & - & - & 80 & - \\
\hline Above ground residues & 8,950 & $15 / 08 / 05$ & 0.57 & 1.07 & 40.2 & $70: 1$ & 51 & 3,600 \\
\hline Below ground residues & 5,000 & $15 / 08 / 05$ & 0.66 & 0.81 & 33.4 & $51: 1$ & 33 & 1,670 \\
\hline Green harvest residues & 10,000 & $30 / 10 / 06$ & 0.41 & 0.83 & 44.4 & $108: 1$ & 41 & 4,400 \\
\hline
\end{tabular}

${ }^{\dagger}$ Above ground (AGR) and below ground residues (BGR) = aerial part and root system of last sugarcane ratoon of variety RB855536 in crop renewal, respectively; green harvest residues (GHR) was generate during plant cane harvest of SP81-3250 variety.
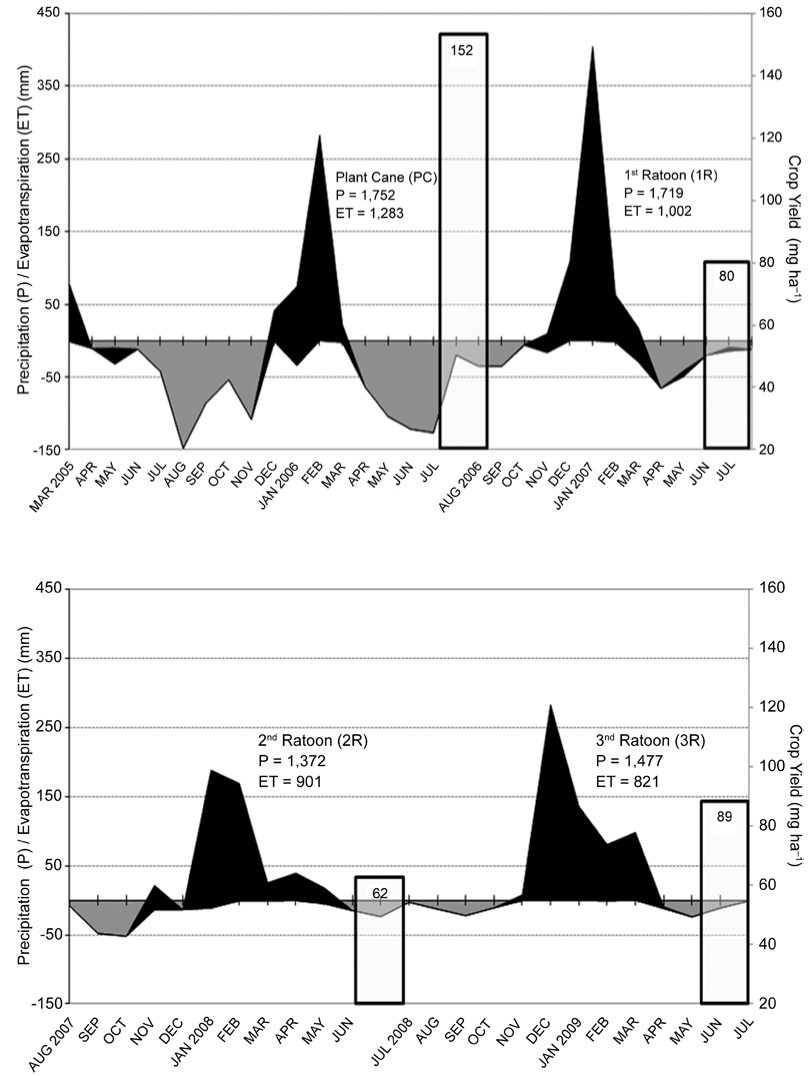

Figure 2 - Water balances (gray and black areas) and average yields (bars) of the evaluated sugarcane crops (Mar. 2005 to Jul. 2009). $\mathrm{P}=$ precipitation and $\mathrm{ET}=$ evapotranspiration $(\mathrm{mm}) ; \mathrm{TCH}=$ average yield of each year ( $\mathrm{Mg}$ ha ${ }^{-1}$ of millable stalks); $\mathrm{PC}=$ plant cane; $\mathrm{R}=$ ratoons.

Beyond assessing the contribution of previous crop residues in sugarcane $\mathrm{N}$ nutrition, another study was addressed to quantify the amount of $\mathrm{N}$ from post-harvest trash, recovered by the subsequent ratoons. Therefore, the original post-harvest trash was replaced by a ${ }^{15} \mathrm{~N}$ green harvest trash gathered from plant cane microplots of this (Fortes et al., 2012) and other trials (Franco et al., 2010; Vitti et al., 2010) using the same variety SP81-3250 (Table 1). For this treatment the residues were fixed onto the soil surface with nylon screen and staples as outlined before, in four $2.0 \times 1.5 \mathrm{~m}$ micro plot replicates and installed in two distinct $\mathrm{N}$ treatments of ratoon cane, 0 and $150 \mathrm{~kg} \mathrm{ha}^{-1}$ of $\mathrm{N}$-ammonium nitrate (N-AN) applied annually as top dressing (Figure 2). The hypothesis was that mineral $\mathrm{N}$ application over the trash blanket could increase the recovery of $\mathrm{N}$-trash by sugarcane due to reduction of trash $\mathrm{C}: \mathrm{N}$ ratio and enhance conditions for microbial activity and crop rooting.

\section{${ }^{15} \mathrm{~N}$-Microplot sampling, $\mathrm{N}$ recovery and $\mathrm{C}$ and $\mathrm{N}$ balances}

Micro plots were annually harvested after 12 months for each crop (2006 to 2009). The above ground biomass, contained in the central $1.0 \mathrm{~m}$ segment as well as in the two adjacent rows, was separated into stalks, dry leaves and tops, as described in Trivelin et al. (1994). The fresh mass of each plant part was weighed in the field with an electronic scale and then those parts were passed through a forage chopper and immediately subsampled $( \pm 0.5 \mathrm{~kg})$ and taken to laboratory.

Subsamples were dried in an oven under forced ventilation $\left(65^{\circ} \mathrm{C}\right.$ for $72 \mathrm{~h}$ ) and dry matter (DM) was determined. Similarly to crop residue characterization, the subsamples of plant parts collected in micro plots were analyzed for total $\mathrm{C}$ and $\mathrm{N}\left(\mathrm{g} \mathrm{kg}^{-1}\right)$ and concentration of ${ }^{15} \mathrm{~N}$ by mass spectrometry (Barrie and Prosser, 1996). The $\mathrm{N}$ in plant parts derived from ${ }^{15} \mathrm{~N}$ sources (NPPS, in $\mathrm{kg} \mathrm{ha}^{-1}$ ) was assessed according to the isotopic dilution calculation (Trivelin et al., 1994).

After the last crop (2009) harvest, soil samples were taken with a metal core sampler at three distances within the micro plots: over the central cane row, 0.30 and $0.60 \mathrm{~m}$ perpendicularly away from the central row and in two depths, $0-0.30$ and $0.30-0.60 \mathrm{~m}$ in order to obtain the residual ${ }^{15} \mathrm{~N}$ after the consecutive crops in the soil. Samples were also used to measure soil bulk density as described in Basanta et al. (2003) and Gava et al. (2005). These distances and depths were adopted since they comprise more than $80 \%$ of the sugarcane root system, according to Otto et al. (2009). A specific probe for root sampling $(0.055 \mathrm{~m}$ in diameter) was used for the $0-0.30 \mathrm{~m}$ soil layer while for the $0.30-0.60 \mathrm{~m}$ depth a conventional soil probe $(0.03 \mathrm{~m})$ was employed pursuing to increase the detection ability of ${ }^{15} \mathrm{~N}$.

Additionally, a destructive sampling of the sugarcane rhizomes of the central meter of the micro plots 
was performed in order to assess the full $\mathrm{N}$ balance in the soil-plant system, right after evaluation of each crop (2006 to 2009). The adhered soil and roots were separated from cane rhizomes and then washed, weighed on analytical scale and oven dried under forced ventilation $\left(65^{\circ} \mathrm{C}\right.$ for $72 \mathrm{~h}$ ) for DM determination. Further, the soil samples were air dried and both, rhizomes and soil, were finely ground in a Willey mill and $\mathrm{C}, \mathrm{N}$ and ${ }^{15} \mathrm{~N}$ levels were measured by mass spectrometry (Barrie and Prosser, 1996).

All ${ }^{15} \mathrm{~N}$ recovery data in plant and soil were analyzed using analysis of variance (ANOVA). Least significant differences (LSD) were assessed by Tukey Studentized Test among $\mathrm{N}$ recoveries during crops whilst regression analysis was used for $\mathrm{N}$ recovery and evapotranspiration data. Tests were performed considering 10, 5 and $1 \%$ probability levels.

\section{Results and Discussion}

$\mathrm{N}$ recovery by sugarcane from urea and previous crop residues (above ground and below ground) in four consecutive crops (2006 to 2009)

The amount of $\mathrm{N}$-urea recovered by plant cane was $24.7 \mathrm{~kg} \mathrm{ha}^{-1}$, equivalent to $31 \%$ of $\mathrm{N}$ rate initially applied. Those results were consistent with Franco et al. (2010) which observed recovery of $28 \%$ of N-urea by the plant cane for the average of two other sites in the Sao Paulo State using the same variety, $\mathrm{N}$ source and rate 180 $\mathrm{kg}$ of $\mathrm{N} \mathrm{ha}^{-1}$ ). After plant cane, the recovery of $\mathrm{N}$-urea applied at planting remained constant as $15 ; 4$; and $3 \%$ relative to first, second and third ratoons, respectively). The sum of $\mathrm{N}$ recovery by sugarcane during all crop seasons reached $43 \%$ (Table 2).

After the plant cane, the $\mathrm{N}$ fertilizer was turned over into other forms of organic $\mathrm{N}$ in soil (SOM, roots, microorganisms) but remained as a pool of available $\mathrm{N}$ for the crop, as pointed by Hemwong et al. (2009) and Dourado Neto et al. (2010). Leaching losses of fertilizer $\mathrm{N}$ in plant cane grown in Brazil were assumed to be insignificant as observed by Ghiberto et al. (2009) using ${ }^{15} \mathrm{~N}$-enriched fertilizer in a similar study but carried out in a much sandier soil. The $\mathrm{N}$ fertilizer must be readily available to plants as it is absorbed in higher quantities during the early growth stages and decreases over the cycle, and in the same way, that this nutrient is also lost by the crop canopy during senescence (Franco et al., 2011; Vitti et al., 2010).

The ${ }^{15} \mathrm{~N}$ recovery by plant cane derived from above ground sugarcane residues incorporated into the soil at planting was $13 \%$. For subsequent ratoon, its recovery decreased $\left(7 \%\right.$ for $1^{\text {st }}, 3 \%$ for $2^{\text {nd }}$, and $5 \%$ for $3^{\text {rd }}$ ratoons, respectively). Differently, a higher amount of $\mathrm{N}$ from the below ground part of sugarcane ratoon was recovered by sugarcane in the second ratoon 19 $\%)$ and not in plant cane, where only $6 \%$ of $\mathrm{N}$ was recovered by crop (Table 2). Probably, these results may related to the C:N ratio, lignin, cellulose, hemicellulose and polyphenols contents of each sugarcane compartment which is intrinsically related with $\mathrm{N}$ mineralization (Abiven et al., 2005; Zhang et al., 2008). Indeed, Abiven et al. (2005) found higher levels of decomposition resistant compounds such as lignin and polyphenols as well as higher $\mathrm{C}: \mathrm{N}$ ratios in root residues of several crops in Brazil when compared to their leaf residues. However, the $\mathrm{C}: \mathrm{N}$ ratio found for root residues in our study was lower than that for leaf residues (sugarcane trash), 51:1 for root residues against 70:1 for above ground residues (Table 1). Therefore, differences in $\mathrm{N}$ recovery by sugarcane from those residues were mainly driven by the climatic conditions prevailing during crop development and by the intense root growth under the trash blanket, which consequently reduced the $\mathrm{C}: \mathrm{N}$ ratio of residues, enhancing $\mathrm{N}$ release and plant uptake of N (Cheng and Coleman, 1990; Vitti et al., 2010).

The nutrient release rates from plant residues are also related to their intrinsic quality such as total nutrient content (Oliveira et al., 2002; Zhang et al., 2008) which also dictate the degree of residue turnover into SOM, because during crop residue decomposition $\mathrm{N}$ is

Table 2 - Recovery of ${ }^{15} \mathrm{~N}$ from Urea, residues from last sugarcane ratoon (above and below ground parts) by sugarcane after four consecutive crops (2006 to 2009).

\begin{tabular}{|c|c|c|c|c|c|c|c|c|c|}
\hline \multirow[b]{3}{*}{ Crop Season } & & & & \multicolumn{6}{|c|}{ Residues from last sugarcane ratoon } \\
\hline & \multicolumn{3}{|c|}{ Urea } & \multicolumn{3}{|c|}{ Above ground } & \multicolumn{3}{|c|}{ Below ground } \\
\hline & $\mathrm{kg} \mathrm{ha}^{-1}$ & $\%$ & & $\mathrm{~kg} \mathrm{ha}^{-1}$ & $\%$ & & $\mathrm{~kg} \mathrm{ha}^{-1}$ & $\%$ & \\
\hline 2006 & 24.7 & 30.9 a & & 6.7 & $12.8 \mathrm{a}$ & & 2.0 & $6.1 \mathrm{ab}$ & \\
\hline 2007 & 3.9 & $4.9 \mathrm{~b}$ & & 3.7 & $7.3 b$ & & 3.1 & $9.4 \mathrm{a}$ & \\
\hline 2008 & 2.9 & $3.6 \mathrm{~b}$ & & 1.3 & $2.6 \mathrm{c}$ & & 0.5 & $1.5 \mathrm{c}$ & \\
\hline 2009 & 2.8 & $3.5 b$ & & 2.4 & $4.7 \mathrm{bc}$ & & 1.8 & $5.3 b$ & \\
\hline 2006-2009 & 34.3 & 42.8 & & 14.2 & 27.5 & & 7.4 & 22.4 & \\
\hline$\overline{\mathrm{LSD}}$ & 3.0 & 3.8 & ** & 1.8 & 3.5 & ** & 1.2 & 3.7 & ** \\
\hline CV \% & \multicolumn{2}{|c|}{18.7} & & \multicolumn{2}{|c|}{17.0} & \multicolumn{4}{|c|}{22.4} \\
\hline
\end{tabular}

LSD = least significant difference; CV $\%=$ coefficient of variation. Same letters in a column indicate no differences (Tukey Studentized test; ns $=$ no significance, ${ }^{* *}=1 \%$ probability level). 
partitioned into three pools: mineral N (soil and fertilizer), humic acids and immobilized $\mathrm{N}$ in soil microbial biomass, hence there is a continuous transformation of $\mathrm{N}$ among these soil-plant system pools (Dourado Neto et al., 2010).

Nitrogen from above ground residues had the same behavior as $\mathrm{N}$-urea, mainly during plant cane growth (higher $\mathrm{N}$ recovery), with lower recoveries in subsequent ratoons (Table 2). This fact may indicate that $\mathrm{N}$-urea added at sugarcane planting promotes an increased trash mineralization due to the reduction of the C:N ratio of these materials. Moreover, the deficient soil aeration under reduced tillage may have reduced the early degradation of root residues in comparison to above ground residues (Figure 2).

The differences among crop season recoveries of $\mathrm{N}$ from sugarcane residues might be related to weather condition. The favorable climatic condition (higher rates of evapotranspiration) that took place during plant cane and fist ratoon development may have enhanced $\mathrm{N}$ mineralization of crop residues as well as increased

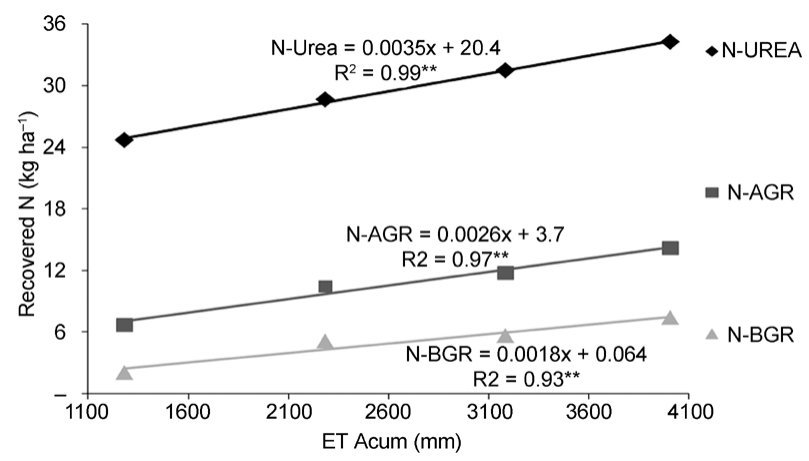

Figure 3 - Correlations between ${ }^{15} \mathrm{~N}$ recoveries from urea; PCT and PCR and the evapotranspiration (ET) after four sugarcane crops (2006 to 2009). ET Acum = Accumulated evapotranspiration in $\mathrm{mm}$ (2005 to 2009); N-UREA = N recovered from nitrogen fertilizer used at planting $\left({ }^{15} \mathrm{~N}-\right.$ urea); N-AGR and N-BGR $=\mathrm{N}$ recovered from the above ground and below ground residues $\left({ }^{15} \mathrm{~N}\right.$ labeled dry leaves and rhizomes, variety RB855536, respectively); ${ }^{*}=1 \%$ probability level. crop yield (Figure 2). Meier et al. (2006) verified lower recoveries of $\mathrm{N}$ from fertilizer $(6 \%)$ and trash $(5 \%)$ in sites located in northeastern of Australia, which was attributed to the higher intensity of rainfall and occasional waterlogging in sugarcane fields.

The weather conditions had directly correlation with crop residue degradation and $\mathrm{N}$ uptake by crops (Figure 3). Robertson and Thorburn (2007b) also observed correlations between trash degradation and $\mathrm{N}$ recovery rates by sugarcane and weather in Tropical sites in Australia. Their results showed that evapotranspiration (ET) was the most determinant factor in $\mathrm{N}$ recovery by the plant.

The total amount of $\mathrm{N}$ applied by both sugarcane crop residues (above and below ground) was $84 \mathrm{~kg} \mathrm{ha}^{-1}$, of which $22 \mathrm{~kg} \mathrm{ha}^{-1}$ (or $26 \%$ ) were recovered by the sugarcane after four cropping seasons. This result reinforces the idea that plant residues comprise a slow release source (pool) of $\mathrm{N}$ to the soil-plant system, as well as other nutrients, especially $\mathrm{K}$ and $\mathrm{Ca}$ (Fortes et al., 2012).

$\mathbf{N}$ from green harvest residues recovery by sugarcane in three consecutive crop seasons (2007 to 2009)

The use of $\mathrm{N}$ from green ratoon harvest residues was higher when $\mathrm{N}$-fertilizer $\left(150 \mathrm{~kg} \mathrm{ha}^{-1} \mathrm{~N}\right)$ was applied. The $\mathrm{N}$ recoveries observed for the first ratoon (2007) in treatments with and without $\mathrm{N}$ reached $8 \%$ and $11 \%$, respectively (Table 3). Results were consistent with the findings of Chapman et al. (1992) and Gava et al. (2005) who obtained $5 \%$ to $9 \%$ of $\mathrm{N}$-trash recoveries by sugarcane after one year. However, at the end of three crops (2007 to 2009), the N recovery by sugarcane almost doubled due to $\mathrm{N}$-fertilizer application (17 against $31 \%$ of the total $\mathrm{N}$ of the green harvest residues, respectively, 0 and $150 \mathrm{~kg} \mathrm{ha}^{-1}$ of $\mathrm{N}$ ).

As aforementioned, the low degradability of sugarcane trash is also related to its high $\mathrm{C}: \mathrm{N}$ ratio, varying from 70:1 to 120:1 (Gava et al., 2005; Meier et al., 2006; Oliveira et al., 2002; Robertson and Thorburn, 2007ab) while Spain and Hodgen (1994) reported 170:1, one of the highest values in literature. Therein, lower rates of net mineralization of green harvest residues are expected in short-term, although the $\mathrm{N}$ supplied by fertilization

Table 3 - Recovery of ${ }^{15} \mathrm{~N}$ from green harvest residues by sugarcane ratoon after three consecutive cycles (2007 to 2009 ).

\begin{tabular}{|c|c|c|c|c|c|c|c|c|c|c|c|c|}
\hline \multirow{3}{*}{$\begin{array}{l}\text { Crop Season } \\
\text { Treatments }\end{array}$} & \multicolumn{12}{|c|}{ Recovery of ${ }^{15} \mathrm{~N}$ by sugarcane ratoon } \\
\hline & \multicolumn{3}{|c|}{2007} & \multicolumn{3}{|c|}{2008} & \multicolumn{3}{|c|}{2009} & \multicolumn{3}{|c|}{$2007-2009$} \\
\hline & $\mathrm{kg} \mathrm{ha}^{-1}$ & $\%$ & & $\mathrm{~kg} \mathrm{ha}^{-1}$ & $\%$ & & $\mathrm{~kg} \mathrm{ha}^{-1}$ & $\%$ & & $\mathrm{~kg} \mathrm{ha}^{-1}$ & $\%$ & \\
\hline Green harvest residues without N-fertilizer & 3.1 & $7.5 \mathrm{a}$ & & 0.9 & $2.1 \mathrm{a}$ & & 3.0 & $7.4 \mathrm{a}$ & & 6.9 & $16.9 \mathrm{a}$ & \\
\hline Green harvest residues with N-fertilizer & 4.6 & $11.3 \mathrm{~b}$ & & 1.9 & $4.7 \mathrm{~b}$ & & 6.1 & $14.8 \mathrm{~b}$ & & 12.6 & $30.7 \mathrm{~b}$ & \\
\hline$\overline{\mathrm{LSD}}$ & 1.5 & 3.6 & $\#$ & 1.0 & 2.3 & ** & 1.7 & 4.2 & ** & 2.3 & 5.6 & ** \\
\hline CV \% & \multicolumn{2}{|c|}{23.1} & & \multicolumn{2}{|c|}{17.2} & & \multicolumn{2}{|c|}{9.2} & \multicolumn{3}{|c|}{5.7} & \\
\hline
\end{tabular}

LSD = least significant difference; CV \% = coefficient of variation. Same letters in a column indicate no differences (Tukey Studentized test; ns $=$ no significance, ${ }^{\star *}$ and $\#=1 \%$ and $10 \%$ probability level). 
may increase $\mathrm{N}$ recovery by the crop (Table 3). Likewise, the $\mathrm{N}$ from green harvest residues becomes stored in the soil pool for future crops while it improves sugarcane rooting capability as pointed by Fortes et al. (2012).

\section{$\mathrm{N}$ balance in the soil-plant system after four sugar-} cane cycles (2006 to 2009)

The N-urea applied at planting $\left(80 \mathrm{~kg} \mathrm{ha}^{-1} \mathrm{~N}\right)$ was the $\mathrm{N}$ source which provided the highest $\mathrm{N}$ recovery by sugarcane after four crops, representing $43 \%$ of total applied N (Figure 4). However, at the same time this source showed the highest amount of uncountable $\mathrm{N}$ in the agro-ecosystem $(37 \%)$, hereafter named as $\mathrm{N}$ in other compartments - NOC. The NOC comprised N$\mathrm{NO}_{3}{ }^{-}$losses by leaching below $0.60 \mathrm{~m}$ in soil profile, $\mathrm{N}$ $\mathrm{NH}_{3}$ volatilization from the soil or by plant canopy and by $\mathrm{N}-\mathrm{N}_{2} \mathrm{O}$ denitrification (Trivelin et al., 2002; Thorburn et al., 2011). Basanta et al. (2003) evaluated the recovery of $\mathrm{N}$-fertilizer by sugarcane in Brazil during three crops and found that $29 \%$ remained in the soil, $42 \%$ was used by plant and $29 \%$ was lost as NOC, a result very similar to ours. According to Dourado Neto et al., (2010) and Franco et al. (2011) N from fertilizers has low capacity to replenish $\mathrm{N}$ stocks in SOM although fertilizers represent an immediate source of $\mathrm{N}$ for crops.

The crop residues incorporated into the soil during sugarcane pre planting operation were low effective to supply $\mathrm{N}$ for sugarcane nutrition (Table 2), but may have an important role for sustainability in tropical agro-ecosystems due to its contribution in supplying organic $\mathrm{C}, \mathrm{N}$ and other nutrients for the soil organic matter in long-term (Thorburn et al., 2011). Indeed, the fate of above and below ground residues from last crop

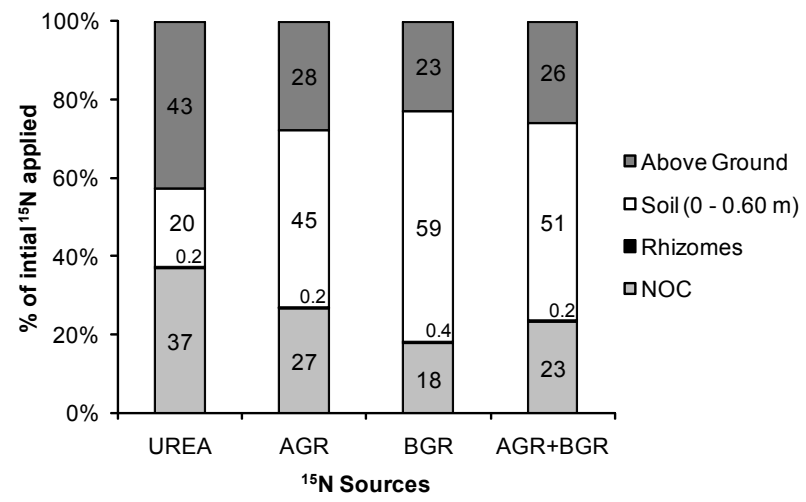

Figure $4-\mathrm{N}$ balances from ${ }^{15} \mathrm{~N}$ sources (urea, $\mathrm{PCT}$ and PCR) in the soil-plant system after four sugarcane crops (2006 to 2009). AGR and $\mathrm{BGR}=$ above ground and below ground residues (dry leaves and rhizomes, variety RB855536, respectively); NOC = nitrogen in other compartments (leaching below $0.60 \mathrm{~m}$, volatilization or denitrification). Numbers inside bars are $\%$ of $\mathrm{N}$ recovery from the initial rate applied. after 5 years (2005 to 2009 ) was in the soil (45\% and 59 $\%$ of total $\mathrm{N}$ present in the above and below ground of sugarcane residues, respectively), highlighting the importance of these materials in providing $\mathrm{N}$ to the soil (Figure 4).

The balance of $\mathrm{N}$ from green harvest residues showed that 69 and $61 \%$ of $\mathrm{N}$ were recovered in the soil for the 0 and $150 \mathrm{~kg} \mathrm{ha}^{-1} \mathrm{~N}$-fertilizer treatments, respectively. Although these results may indicate that treatments with $\mathrm{N}$ fertilizer application was worse than without $\mathrm{N}$, the whole balance revealed that $\mathrm{N}$-fertilizer enhanced the availability of $\mathrm{N}$ from green harvest residues likely due to the reduction of the $\mathrm{C}: \mathrm{N}$ ratio and higher intensity SOM degradation (Fortes et al., 2012; Vitti et al., 2010), added to the increase of crop performance and N uptake (Franco et al., 2008; Franco et al., $2010)$ and to the decrease in NOC (Figure 5). Therefore, $\mathrm{N}$ fertilizer minimized losses in soil-plant system, stressing the importance of considering the interactions of N sources to manage long-term sugarcane fertilization programs (Thorburn et al., 2011). However, Khan et al. (2007) stated that excessive $\mathrm{N}$ fertilization (> $200 \mathrm{~kg} \mathrm{ha}^{-1} \mathrm{year}^{-1}$ ) could lead to decreases in soil organic $\mathrm{C}$ stocks in the long-term due to higher degradation rates of crop residues. Khan et al. (2007) also stressed the importance of maintaining part of crop residues even when they could be collected for power generation from biomass or improving sugarcane crop GHG emissions footprints (Macedo et al., 2008).

Concluding, despite $\mathrm{N}$ fertilization being highly correlated to crop production it can also damage the environment, particularly under intense rainfall conditions Thus the maintenance of plant residues is essential for adequate crop nutrition while mitigating nutrient, soil and water losses (Liu et al., 2010; Thorburn et al., 2011).

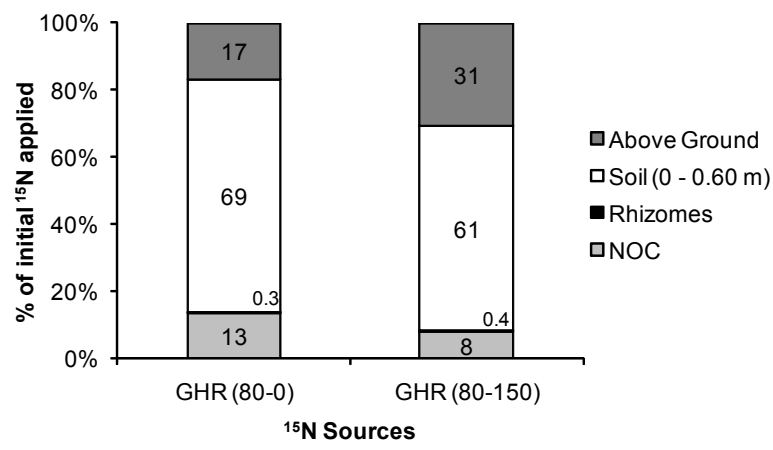

Figure $5-\mathrm{N}$ balances from ${ }^{15} \mathrm{~N}-\mathrm{PHT}$ in the soil-plant system after three sugarcane crops and different treatments in plant cane and ratoons (2007 to 2009). GHR (80-0) = green harvest residues (dry leaves, variety SP81-3250) with 80 and $0 \mathrm{~kg} \mathrm{ha}^{-1}$ of nitrogen in plant cane and ratoons, respectively; GHR (80-150) = green harvest residues (dry leaves, variety SP81-3250) with 80 and $150 \mathrm{~kg} \mathrm{ha}^{-1}$ of nitrogen in plant cane and ratoons, respectively; $\mathrm{NOC}=$ nitrogen in other compartments (leaching below $0.60 \mathrm{~m}$, volatilization or denitrification). Numbers inside bars are $\%$ of $\mathrm{N}$ recovery from the initial rate applied. 


\section{Acknowledgements}

To FAPESP (Proc. 2002/10534-8) and CNPQ (151184/2005-4), for funding; CTC and Sao Martinho mill for the provided resources.

\section{References}

Abiven, S.; Recous, S.; Reyes, V.; Oliver, R. 2005. Mineralisation of $\mathrm{C}$ and $\mathrm{N}$ from root; stem and leaf residues in soil and role of their biochemical quality. Biology and Fertility of Soils 42: 119-128.

Allen, R.G.; Pereira, L.S.; Raes, D.; Smith, M. 1998. Crop Evapotranspiration: Guidelines for Computing Crop Water Requirements. FAO, Rome, Italy. (FAO Irrigation and Drainage Paper, 56).

Ambrosano, E.A.; Trivelin, P.C.O.; Cantarella, H.; Ambrosano, G.M.B.; Schammass E.A.; Guirado, N.; Rossi, F.; Mendes, P.C.D.; Muraoka, T. 2005. Utilization of nitrogen from green manure and mineral fertilizer by sugarcane. Scientia Agricola 62: 534-542.

Barrie, A.; Prosser, S.J. 1996. Automated analysis of light-element stable isotopes by isotope ratio mass spectrometry. p. 1-46. In: Boutton, T.W.; Yamasaki, S.I., eds. Mass spectrometry of soil. Marcel Dekker, New York, NY, USA.

Basanta, M.V.; Dourado-Neto, D.; Reichardt, K.; Bacchi, O.O.S.; Oliveira, J.C.M.; Trivelin, P.C.O.; Timm, L.C.; Tominaga, T.T.; Correchel, V.; Cássaro, F.A.M.; Pires, L.F.; Macedo, L.F. 2003. Management effects on nitrogen recovery in a sugarcane crop grown in Brazil. Geoderma 116: 235-248.

Chapman, L.S.; Haysom, M.B.C.; Saffigna, P.G. 1992. N cycling in cane fields from ${ }^{15} \mathrm{~N}$ labelled trash and residual fertilizer. In: Australian Society of Sugar Cane Technologists, 14, Brisbane. Proceedings, 84-89.

Cheng, W.; Coleman, D. 1990. Effect of living roots on soil organic matter decomposition. Soil Biololgy and Biochemistry 22: 781787.

Dourado-Neto, D.; Powlson, D.; Abu Bakar, R.; Bacchi, O.O.S.; Basanta, M.V.; Cong, P.T.; Keerthisinghe, G.; Ismaili, M.; Rahman, S.M.; Reichardt, K.; Safwat, M.S.A.; Sangakkara, R.; Timm, L.C.; Wang, J.Y.; Zagal, E.; van Kessel, C. 2010. Multiseason recoveries of organic and inorganic nitrogen-15 in tropical cropping systems. Soil Science Society of America Journal 74: 139-152.

Fortes, C.; Trivelin, P.C.O.; Vitti, A.C. 2012 Long-term decomposition of sugarcane harvest residues in Sao Paulo state, Brazil. Biomass \& Bioenergy 42: 189-198.

Franco, H.C.J.; Trivelin, P.C.O.; Faroni, C.E.; Vitti, A.C.; Otto, R. 2010. Stalk yield and technological attributes of planted cane as related to nitrogen fertilization. Scientia Agricola 67: 579-590.

Franco, H.C.J.; Otto, R.; Faroni, C.E.; Vitti, A.C.; Oliveira, E.C.A.; Trivelin, P.C.O. 2011. Nitrogen in sugarcane derived from fertilizer under Brazilian field conditions. Field Crops Research 121: 29-41.

Franco, H.C.J.; Trivelin, P.C.O.; Faroni, C.E.; Vitti, A.C.; Otto, R. 2008. Utilization by sugar cane of nitrogen applied at planting. Revista Brasileira de Ciência do Solo, 32(spe). DOI: http:// dx.doi.org/10.1590/S0100-06832008000700021 (in Portuguese, with abstract in English).
Gava, G.J.C.; Trivelin, P.C.O.; Vitti, A.C.; Oliveira, M.W. 2005. Urea and sugarcane straw nitrogen balance in a soilsugarcane crop system. Pesquisa Agropecuaria Brasileira 40: 689-695.

Ghiberto, P.J.; Libardi, P.L.; Brito, A.S.; Trivelin, P.C.O. 2009. Leaching of nutrients from a sugarcane crop growing on an Ultisol in Brazil. Agricultural Water Management 96: 14431448.

Hemwong, S.; Toomsan, B.; Cadisch, G.; Limpinuntana, V.; Vityakon, P.; Patanothai, A. 2009. Sugarcane residue management and grain legume crop effects on $\mathrm{N}$ dynamics, $\mathrm{N}$ losses and growth of sugarcane. Nutrient Cycling in Agroecosystems 83: 135-51.

Khan, S.A.; Mulvaney, R.L.; Ellsworth, T.R.; Boast, C.W. 2007. The myth of nitrogen fertilization for soil carbon sequestration. Journal of Environmental Quality 36: 1821-1832.

Liu, J.; You, L.; Amini, M.; Obertsteiner, M.; Herrero, M.; Zehnder, A.J.B.; Yang, H. 2010. A high-resolution assessment on global nitrogen flows in cropland. Proceedings of the National Academy of Sciences of USA 107: 8035-8040.

Lucon, O.; Goldemberg, J. 2010. São Paulo: the "other" Brazil; different pathways on climate change for state and federal governments. Journal of Environmental Development 19: 335337.

Macedo, I.C.; Seabra, J.E.A.; Silva, J.E.A.R. 2008. Green house gases emissions in the production and use of ethanol from sugarcane in Brazil: the 2005/2006 averages and a prediction for 2020. Biomass and Bioenergy 32: 582-595.

Meier, E.A.; Thorburn, P.J.; Wegener, M.K.; Basford, K.E. 2006. The availability of nitrogen from sugarcane trash on contrasting soils in the wet tropics of North Queensland. Nutrient Cycling in Agroecosystems 75: 101-114

Ng Kee Kwong, K.F.; Deville, J.; Cavalot, P.C.; Riviere, V. 1987. Value of cane trash in nitrogen nutrition of sugarcane. Plant and Soil 102: 79-83

Oliveira, M.W.; Trivelin, P.C.O.; Kingston, G.; Barbosa, M.H.P.; Vitti, A.C. 2002. Decomposition and release of nutrients from sugarcane trash in two agricultural environments in Brazil. Proceedings of the Conference of Australian Society of Sugar Cane Technologists 24: 1-10.

Otto, R.; Trivelin, P.C.O.; Franco, H.C.J.; Faroni, C.E.; Vitti, A.C. 2009. Root system distribution of sugar cane as related to nitrogen fertilization, evaluated by two methods: monolith and probes. Revista Brasileira de Ciência do Solo 33: 601-611

van Raij, B.; Andrade, J.C.; Cantarella, H.; Quaggio, J.A. 2001. Análise Química para Avaliação da Fertilidade de Solos Tropicais $=$ Chemical Analysis for Evaluation of the Fertility of Tropical Soils. Instituto Agronômico, Campinas, SP, Brazil 285p.

Robertson, F.A.; Thorburn, P.J. 2007a. Decomposition of sugarcane harvest residue in different climatic zones. Australian Journal of Soil Research 45: 1-11

Robertson, F.A.; Thorburn, P.J. 2007b. Management of sugarcane harvest residues: consequence for soil carbon and nitrogen. Australian Journal of Soil Research 45: 13-23

United States Department of Agriculture [USDA]. 2006. Keys to Soil Taxonomy USDA-Soil Survey Staff, Washington, DC, USA. $341 p$. 
Spain, A.V.; Hodgen, M.J. Changes in the composition of sugarcane harvest residues during decomposition as a surface mulch. 1994. Biology and Fertility of Soils, 17: 225-231.

Thorburn, P.J.; Biggs, J.S.; Webster, S.J.; Biggs, I.M. 2011. An improved way to determine nitrogen fertiliser requirements of sugarcane crops to meet global environmental challenges. Plant and Soil 339: 51-67

Trivelin, P.C.O.; Lara Cabezas, W.A.R.; Victoria, R.L.; Reichardt K. 1994. Evaluation of a ${ }^{15} \mathrm{~N}$ plot design for estimating plant recovery of fertilizer nitrogen applied to sugar cane. Scientia Agricola 51: 226-234.

Trivelin, P.C.O.; Oliveira, M.W.; Vitti, A.C.; Gava, G.J.C.; Bendassolli, J.A. 2002. Nitrogen losses of applied urea in the soil-plant system during two sugar cane cycles. Pesquisa Agropecuária Brasileira 37: 193-201 (in Portuguese, with abstract in English).
Vitti, A.C.; Ferreira, D.A.; Franco, H.C.J.; Fortes, C.; Otto, R.; Faroni, C.E.; Trivelin, P.C.O. 2010. Utilisation of nitrogen from trash by sugarcane ratoons. Sugarcane International 28: 249253

Yasmin, K.; Cadisch, G.; Baggs, E.M. 2006. Comparing ${ }^{15}$ N-labelling techniques for enriching above and below-ground components of the plant-soil system. Soil Biology and Biochemistry 38: 397-400

Zhang, D.; Hui, D.; Luo, Y.; Zhou, G. 2008. Rates of litter decomposition in terrestrial ecosystems: global patterns and controlling factors. Journal of Plant Ecology 1: 85-93 